\title{
Protective pants design for skaters to be analyzed by divergent and convergent thinking concepts
}

\author{
D. Yudiarti \& I. Khofiani \\ Telkom University, Bandung, Indonesia
}

\begin{abstract}
Extreme sports are sports that have challenges that must be faced with a high level of difficulty with a greater risk of accidents than sports in general. Skateboard is one of the extreme sports groups that are currently developing among teenagers. Skateboarding actually has the risk of fatal injuries to the limbs for skaters. They must give up their bodies which often fall during each exercise. Departing from this phenomenon, this study is interested in designing the design of user safety when skateboarding by combining apparel products with existing protectors to overcome minor injuries due to collisions while skateboarding to make it more practical and easier to use. This research conducted a case study method and analyzed by Divergent (analyzed Divergent) and Convergent Thinking Concepts, thus the design is delivered using the SCAMPER design method. The product designed (design) contains a safety function in the knees that assists the skateboarding activity and is applicable to the trends of the skater lifestyle.
\end{abstract}

Keywords: safety equipment, deckers, safety pants, skateboard, skaters

\section{INTRODUCTION}

Sports activities are a necessity of human life and an effective way to improve physical health and physical fitness which thereby improves the quality of human life. The development of extreme sports may still be less popular but it (is) still very attractive to young people today. Extreme sports are sports that are more directed toward a modern style and are more individualistic, with challenges that must be faced with a high level of difficulty (and) a greater risk of accidents than sports in general. Skateboarding is one such extreme sport that is currently developing among teenagers.

Factors that influence the rapid growth of skateboarding in young people and teenagers are the ability to freely express themselves and do anything in the form of movements or tricks on a skateboard (Ace 2006). That is because teenagers have a desire for freedom and enthusiasm. The development of skateboarding can be seen from the emergence of several skateboard communities in every city in Indonesia. Many skateboarders argue that skateboarding is not only a sport but also a lifestyle (Kolinug 2017). This is indicated by the activities carried out intensively by individuals, giving them meaning.

Skateboarding actually comes with a risk of fatality or limb injuries. They must give up their bodies which often fall during each exercise. Departing from this phenomenon, the authors are interested in creating a design of user safety when skateboarding by combining apparel products with existing protectors to overcome minor injuries due to collisions. There are two choices of opportunity, namely the elbows in clothes/jackets or in the knee area. The design is adapted to fashion trends for skaters related to the lifestyle and needs of users. It should also be noted that the design must meet the needs required by the target market of this product so as not to impede the activities being carried out. 


\section{METHODOLOGY}

\subsection{Research method}

In this study, the authors conducted a case study on one of the skateboarding communities in Bandung, precisely in the Pasupati Skatepark area. The area is a gathering place for several skateboarding communities in Bandung that are interconnected. In this design, the authors conducted research with observation and interview techniques.

\subsection{Design strategies}

1. Divergent and convergent thinking analysis were used in managing design problems both in process and practice, which is the decision-making conduct of the event of specifying design materials, working relationships, and ethical responsibilities (Best 2006). Designers are required to narrow the problem space to solve the problem, and there are four basic cognitive steps: generation, exploration, comparison, and selection (Stempfle \& Badke-Schaub 2002).

Considerable imagination is required by designers and can often be unpredictable in its outcome, hence the creative process to manage design problem enhances the Divergent and Convergent Thinking, which are the most crucial things in brainstorming (Yudiarti \& Lantu 2017).

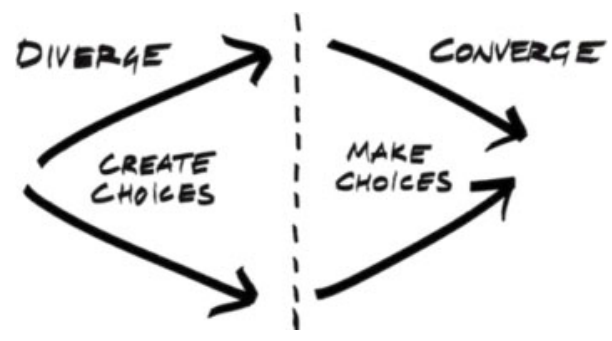

Figure 1. Divergent and convergent thinking. (Source: Brown 2009).

\section{SCAMPER analysis}

SCAMPER is a technique that can be used to develop creativity in a different way from existing ones to trigger and generate new ideas. It can help overcome any challenge that might be encountered in a design (Michalko 2006).

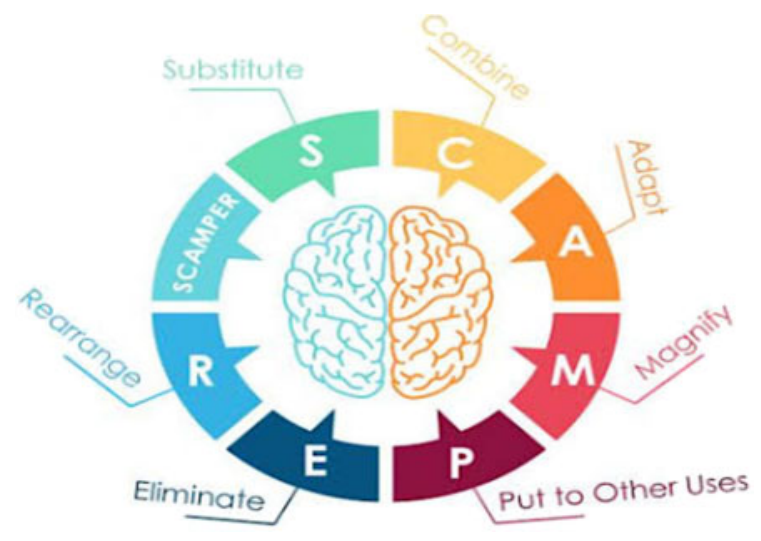

Figure 2. SCAMPER diagram. (Source: Human Resources-UWA). 


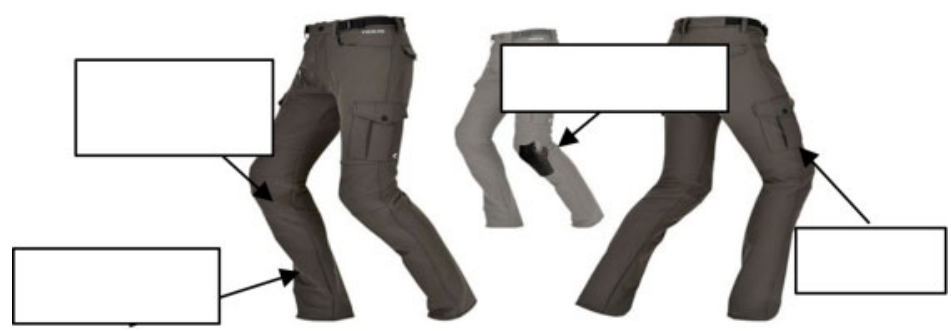

Figure 3. SCAMPER application while analyzing on cargo (analyzing cargo)pants.

SCAMPER is based on the idea that everything new is a modification of something that already exists. SCAMPER is an acronym that stands for

Substitute (Replacing), Combine, Adapt (Adapting), Magnify, Put to Other Use, Eliminate, and Rearrange/Reverse (Michalko 2006).

\section{DISCUSSION OF ANALYSIS}

\subsection{Functional aspects (safety and secure)}

This design process uses the SCAMPER analysis technique. It combines the function of the safety cushion (decker) with the pants or trousers. Based on the functional aspect, the design requirements are pants that are comfortable to use and also serve or provide safety when skateboarding. This product is designed by adjusting (Adapt) existing components on pants and knee pads as the Combine method. The product must be able to contain safety functions in the knees of pants or in areas that assist with the extreme activities. Substitute the pocket functions on the pants, thus the users could put the safety pad inside.

To become a multipurpose product by placing different functions (Put to Another Use), the design requirement needed is the application of the bearing function in certain areas that experience direct impact with the surface when the player falls. Table 1 describes the needs of the activities carried out on the product:

Table 1. Product activity needs.

\begin{tabular}{|c|c|c|}
\hline ACTIVITIES & FACILITIES & DESCRIPTIONS \\
\hline $\begin{array}{l}\text { Users' movement when doing extreme } \\
\text { sports }\end{array}$ & Adequate pants size & $\begin{array}{l}\text { Pant size ratio must adjust to the } \\
\text { range of activities }\end{array}$ \\
\hline $\begin{array}{l}\text { User position when performing trick } \\
\text { moves }\end{array}$ & $\begin{array}{l}\text { Comfortable pants } \\
\text { material }\end{array}$ & $\begin{array}{l}\text { The material requirements used, } \\
\text { must be comfortable and not hamper } \\
\text { all the activities }\end{array}$ \\
\hline $\begin{array}{l}\text { Idle moment of users between activi- } \\
\text { ties }\end{array}$ & Casual design & $\begin{array}{l}\text { The pants designed could be used and } \\
\text { applied in any situation }\end{array}$ \\
\hline Users' positions when falling & Safety pad & $\begin{array}{l}\text { Product application is suitable and } \\
\text { the materials are easy to find }\end{array}$ \\
\hline
\end{tabular}

Cargo pants have a slightly complex component that can be dealt with by a little extra design that doesn't really change the overall appearance. By inserting these bearing components, it becomes as if a new bag is in the cargo pants. To place the position of these bearings, analysis is needed on what areas need the most function. Table 2 details the various injury positions in the foot area when skateboarding. 
Table 2. Indicator type of injury positions when falling in the leg area.

\begin{tabular}{lcccc}
\hline Indicator & hip & knee & buttocks & tibia \\
\hline Intensity occurred & $\sqrt{ }$ & $\sqrt{ }$ & $\sqrt{ }$ & $\sqrt{ }$ \\
Fit dimensions & $\sqrt{ }$ & $\sqrt{ }$ & - & $\sqrt{ }$ \\
Materials easy to find & - & $\sqrt{ }$ & - & $\sqrt{ }$ \\
Easy and applicable design & $\sqrt{ }$ & $\sqrt{ }$ & $\sqrt{ }$ \\
\hline
\end{tabular}

From the analysis of the user's injury positions during falls, it was concluded that this design implements safety equipment that protect the knee and tibia areas. The sections are adjusted to the cargo pants which are designed to be comfortable for the user during extreme activities.

\subsection{Terms of Reference (TOR)}

\section{Design Description}

a. The main function of the product is to enable users to have more practical equipment without interfering with their activities.

b. These pants are made with the aim that the user has a new alternative to safety equipment products that accommodate users while skateboarding. This product is expected to overcome the injury problems that arise when skateboarding.

2. Design Requirements

a. The function needed is the addition of a safety pad in the knee area to the tibia as a component in the pants.

b. The type of pants designed are cargo pants so that the bearing components are easily applied.

3. Design Limits

a. The safety cushion feature to be applied only focuses on the knee and shin area based on the results of the analysis.

b. Products are designed only for types of cargo pants.

c. Bearing components only serve as a barrier to injury because the impact is not for blisters or damage due to surface friction.

\section{VISUALIZATION AND FINAL DESIGN}

\subsection{Styleboard}

The mood board concept created in Figure 4 refers to the old-school fashion style theme which is a trend among skaters. The style board shows various mix and match outfits that are used as a source of ideas in the design process.

\subsection{Final design}

Each element of the selected alternative sketches is combined into a new final design. The pockets in the thigh area are taken from the concept of the alternative sketch, and the final design has a simpler appearance with no collision between components. The pockets area of the safety pad on the knee area is structured, so it is easy to operate. There is an elastic part above the knee to facilitate user movements, and on the top of that part is a zipper applied as an additional option so that the pants can be changed into shorts. 


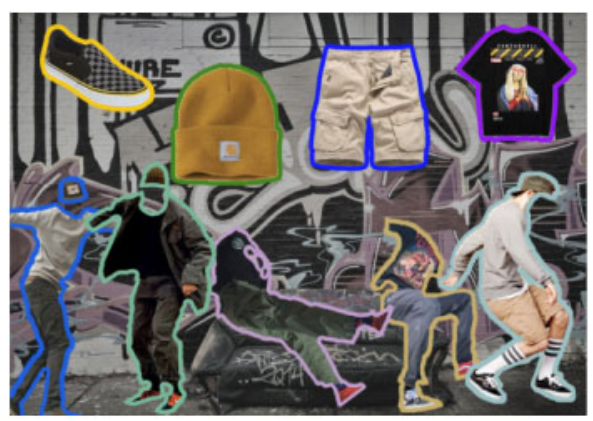

Figure 4. Style board users.
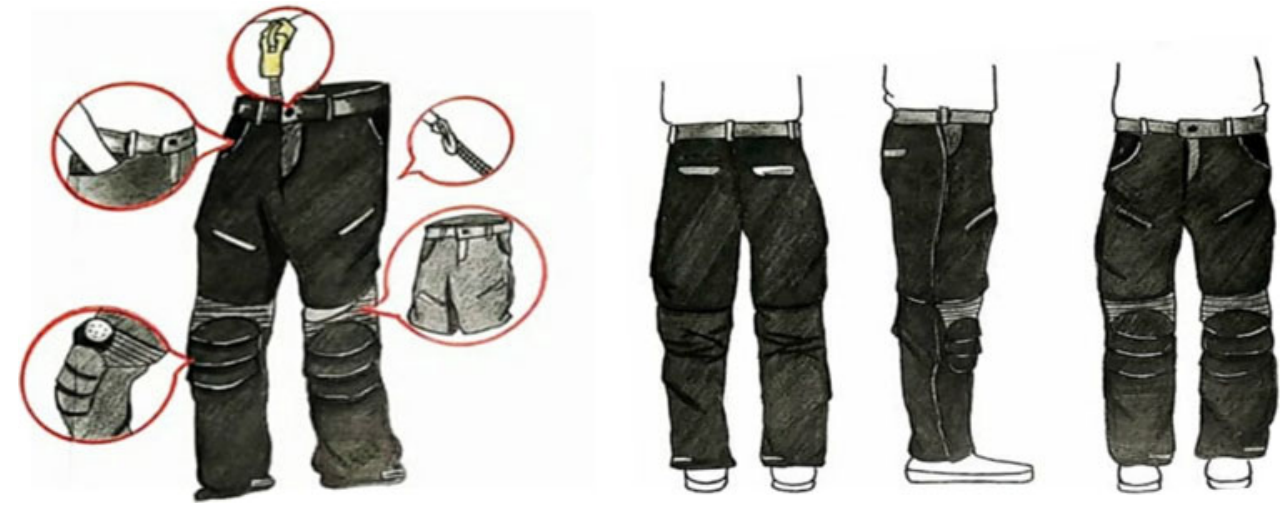

Figure 5. Final design detailing.
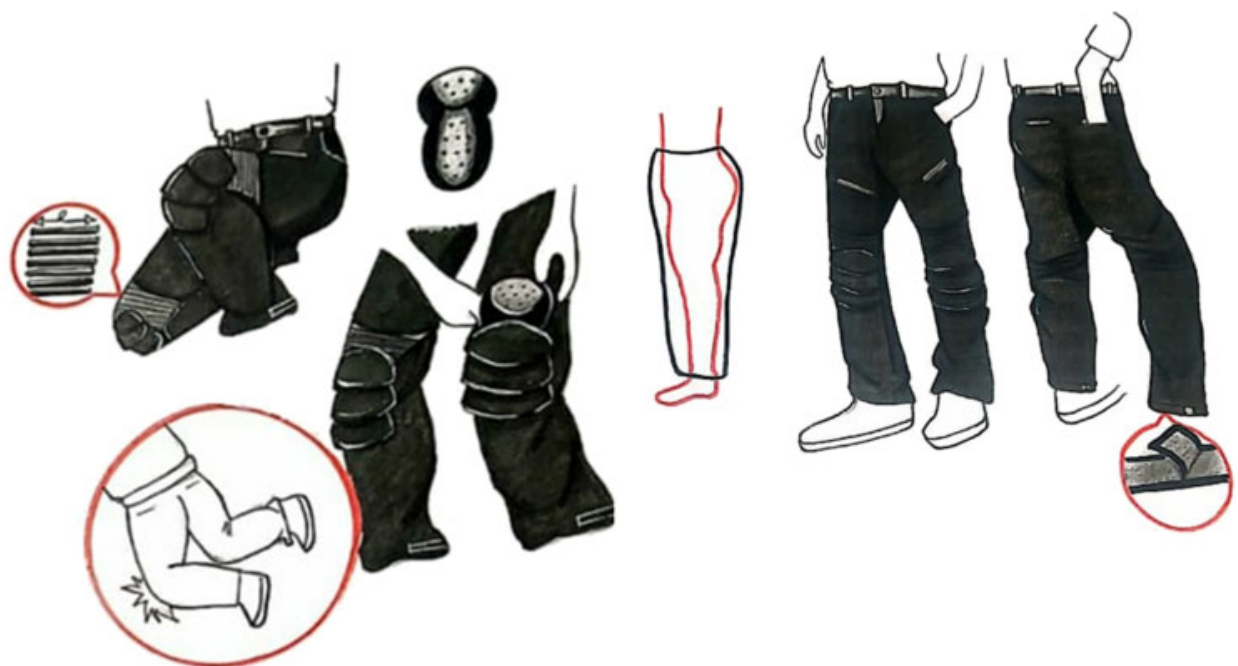

Figure 6. Operational product. 


\section{CONCLUSION}

These protective pants for skaters are designed with an additional pocket for safety pads on the knee area that serves as a barrier to injury due to impact, but not for blisters or damage due to surface friction. The material used is twill which has a texture of fabric fibers that form diagonal lines. The choice of material is because the twill material has the advantages of being durable, strong, and not rigid. This product is equipped with supporting components of the model on cargo pants in general, such as the number of dominant pockets and loose size. For the next design development, the application of a safety system can be replaced or re-developed with a design that is more complex in function not only to withstand collisions. The need for further exploration is related to the trends and lifestyles of target users (skaters) that adjust to the activities carried out more broadly. The design exploration can be even more varied with the addition of other supporting compartments or different fashion styles. In addition, there is a need for a deeper study of the bearings to be used in order to save learning production costs in a more interesting form.

\section{REFERENCES}

Ace. 2006. Speed \& light: Indonesian skateboarding. Jakarta: GagasMedia.

Best, K. 2006. Design Management: Managing Design Strategy, Process and Implementation. AVA Publishing.

Brown, T. 2009. Change by Design: How Design Thinking Transforms Organizations and Inspires Innovation. Harper Collins Publisher.

Kolinug, A. A. 2017. Eksistensi Komunitas Skateboard Di Kota Manado. Holistik, Journal Of Social and Culture. https://ejournal.unsrat.ac.id/index.php/holistik/article/viewFile/17448/16981, Retrieved Februari 24, 2020.

Michalko, M. 2006. Thinkertoys: A Handbook of Creative-Thinking Techniques.

Nurpramadya, A. and Irawan, A. H. 2012. Perancangan Buku Visual Skateboard Untuk Remaja Indonesia. Jurnal Sains dan Seni ITS, 1(1):F17-F21. http://ejurnal.its.ac.id/index.php/sains_seni/article/view/502, downloaded at 27 Februari 2020.

Stempfle, J. and Badke-Schaub, P. 2002. Thinking in Design Teams: An Analysis of Team Communication. Design Studies, 23:473-496.

Yudiarti, D. and Lantu, D.C. 2017. Implementation Creative Thinking for Undergraduate Student: A Case Study of First Year Student in Business School. Advanced Science Letters, 23(8):7254-7257. 